\title{
Experienced stress among nursing teams in primary health care
}

\author{
Nijole Galdikiene ${ }^{* 1,2}$, Paula Asikainen ${ }^{3}$, Sigitas Balciunas ${ }^{4}$, Tarja Suominen ${ }^{1}$ \\ ${ }^{1}$ School of Health Sciences, Nursing Science, University of Tampere, Finland \\ ${ }^{2}$ Department of Nursing, Klaipeda State University of Applied Sciences, Lithuania \\ ${ }^{3}$ Satakunta Hospital District, University of Tampere, Finland \\ ${ }^{4}$ Public Administration Department, Social Research Center, University of Siauliai, Lithuania
}

Received: December 21, 2015

DOI: $10.5430 /$ cns.v4n1p81
Accepted: January 24, 2016

Online Published: February 2, 2016

\begin{abstract}
This research looks to describe experienced stress in nursing teams working in primary health care. Recent changes and increased demands in primary health care may result in highly stressed teams, which have a subsequent impact on nursing care. Nurses' experienced stress has previously been identified at individual, team, organizational and cultural levels. Team related factors associated with stress have been identified as team climate, supportive colleagues and work environment. A descriptive study was conducted among nurses from 29 teams in 18 different primary health care centres, located in one Lithuanian county. The Expanded Nursing Stress Scale (ENSS) was used. A total of 187 nurses completed the questionnaire. The stress experienced by nurses depends on the team. The study results reveal both individual and team level stress. The effect of the team size is moderate, but the background factors of the teams had little association with the sub-categories of stress. Workload tended to cause more stress in larger teams. At the nurses' team level, a strong positive correlation was found between all of the stress subcategory areas investigated, except for that of "discrimination". Different teams followed different stress profiles, but based on their common features, various clusters were identified which should be noticed by management.
\end{abstract}

Key Words: Primary health care, Nurses, Stress, Team

\section{INTRODUCTION}

Stress in nursing has attracted considerable attention as a focus for research, and as consequence, multiple stressors have been identified. ${ }^{[1]}$

Stress is a complex phenomenon which results from an interaction between individuals and their work environment, local forces, pressures and culture, and this often requires customized interventions. ${ }^{[2]}$ A comprehensive review of the literature has identified six main stressors in nurses' work. ${ }^{[3]}$ These are: workload (inadequate staff cover or time pres- sure); relationships with other clinical staff; leadership and management style, lack of adequate supervisory support, coping with the emotional needs of patients and their families, poor patient diagnosis, death and dying, shift working, and lack of reward. There is a large and growing body of knowledge of the stressors that nurses experience and findings suggest that these have changed over time. ${ }^{[4]}$ The occupational stressors nurses encounter can differ between countries, ${ }^{[5]}$ between urban and rural areas, ${ }^{[6]}$ and between hospitals and primary health care. ${ }^{[7]}$ The major sources of stress for nurses

*Correspondence: Nijole Galdikiene; Email: n.galdikiene@kvk.lt; Address: Klaipeda State University of Applied Sciences, Jaunystes str.1, LT 91274, Klaipeda, Lithuania. 
employed in primary health care settings were identified as their workload, conflicts with physicians, and conflicts with other nurses. To a lesser extent, inadequate preparation, lack of support, encountering death and dying, and uncertainty concerning treatment were also reported ${ }^{[7]}$ Stress issues continue to exert influence on dissatisfaction and turnover for nurses. ${ }^{[8-10]}$

Although there is a lack of studies which focus on perceived stress among nursing teams in primary health care, there are studies based on the experiences of individual nurses. Individual characteristics such as age, nursing education and experience have been reported to affect the perception of stress. Researchers have also found that younger public health nurses with a shorter length of current work experience, a higher level of education, and less per-job continuing education perceive a higher level of occupational stress. ${ }^{[11,12]}$

Lenthall et al. ${ }^{[13]}$ synthesized the literature identifying the stresses experienced by remote area nurses (RANs). They found that the reported demands experienced by RANs could be grouped into four themes: the remote context; workload and extended scope of practice; poor management; and violence in the workplace and community. With rural psychiatric nurses, "workload" was the highest perceived stressor followed by "inadequate preparation". ${ }^{[14]}$ For district nurses, the most stressful reported aspects of their work included work overload, climate of change, complex care needs, and a lack of teamwork with other departments. ${ }^{[15]}$ In long-term care, nurses' occupational stress, psychological morale and job satisfaction were found to be influenced by conflict resolution styles, individual characteristics, work demands and work resource factors. ${ }^{[16]}$ In municipality-based elderly care, nursing personnel reported various factors generating a stress of conscience (stress caused by a troubled conscience). ${ }^{[17]}$ Among community hospice nurses, the provision of stressawareness training has been highlighted as a preventative measure for dealing with stress. ${ }^{[18]}$

Although stress has been thoroughly investigated among health care professionals, the focus has mainly been on individual experiences, and what happens in the teams has seldom been a central issue. Tucker et al. ${ }^{[19]}$ investigated 23 workgroups and found a stress-exacerbating effect on anxiety and satisfaction when there was a mismatch between collective efficacy and control. The stressor-strain relationship was also found to be moderated by both individual and team level factors.

Primary care systems are becoming ever more complex. This complexity concerns organizational structure, relationships (formal and informal) with other sectors, and the range of personnel and their responsibilities. Personnel are expected to work in relationships with specialized hospitals and also with other dimensions of primary health care. The expectations of work arise from broader societal trends, and involve issues such as the promotion of client involvement and increasing electronic developments. These change processes have not pointed towards any single dominating organizational and/or behavioural framework being used. ${ }^{[20]}$ Because of today's increasing demands, we may end up with highly stressed teams in primary health care. From the viewpoint of management, it should be noticed that stressed teams may not have the potential to work and operate effectively, which undoubtedly has an impact on the delivery of nursing care.

Lithuania is one of the Baltic region countries (Estonia, Latvia, Lithuania, Poland and some regions of Russia), which from the 1990's have looked to improve their primary health care and implement reforms to rationalize their health care systems. $^{[21]}$ Primary health care reform in Lithuania has mainly focused on decentralization and strengthening interprofessional collaboration. ${ }^{[22]}$ A primary health centre team in Lithuania usually includes family physicians and community nurses. ${ }^{[23]}$ However, reorganization of the primary health care system has not changed their working relationship. Lithuanian community nurses continue to work in a traditional hierarchical relationship with family physicians. Typically and especially in bigger health care centres, they tend to work in the same offices as the family physicians and do not provide independent patient consultations. ${ }^{[24]}$ Also, a paternalistic approach towards patients by staff, and difficulties in interprofessional interaction have been cited as problems faced by Lithuanian health care sectors. ${ }^{[25]}$

The characteristics of working in teams involved in providing community care for clients with chronic conditions were identified as falling into three categories: shared purpose, working in the team, and tensions within the team. ${ }^{[26]}$ By necessity, nurses are willing to collaborate in teamwork, which in turn is associated with good communication skills and an understanding of the roles of others. ${ }^{[27]}$ However, this collaboration might mean a lack of experienced support for the nurse. District nurses were found to lack the authority to start nurse-led clinics because of a lack of collaborative teamwork, an organizational structure that did not enable nurse-led scheduled appointments, and also the nurses' limited view of their own profession. ${ }^{[28]}$

Team level stress has been reported in some nurse-based studies. For example, in Sweden, Ekedahl and Wengström ${ }^{[29]}$ identified four levels of stress: the individual level, the group level related to the team, the organizational level, and the cultural level where care-philosophy and work codes provide 
a central focus. Some team related factors have been seen to be associated with stress, such as the presence of a team climate and having supportive colleagues. A team climate has also been found to provide support for innovation and have a positive impact on well-being. That well-being was in-turn associated with lower levels of stress reactions. ${ }^{[30]}$ Working with supportive colleagues who respect each other's contribution to the patient care process can go a long way in dealing with the stressors that arise in today's health care environments. A work environment that encourages respectful interactions among team members has been identified as being important for sustaining high quality care and retaining nurses. ${ }^{[31]}$ However, one reason cited by primary care physicians for a higher intention to leave their employment has been found to be those stresses which relate to teamwork. ${ }^{[32]}$

In a Finnish study by Kinnunen-Amoroso, ${ }^{[33]}$ an occupational health team of nurses and physicians reported that while work-related stress was rarely assessed, there were often no protocols for when, how or who to contact in this regard. Further interventions at an organizational level were rare and only individuals were treated. However, the participants of the study also saw the organization as being responsible for developing solutions for stress-related events. ${ }^{[33]}$ Some organizations have been found to provide either preventive or reactive interventions, like regular team meetings and e-learning training for managers on identifying and managing stress. ${ }^{[34]}$ Also, a simple but inclusive programme which aims to deliver appropriate education to primary care teams (within protected time) has been indicated to overcome barriers to teamwork. ${ }^{[35]}$ Civility may be one way for health care providers to proactively influence their well-being in response to an inevitably stressful work environment, ${ }^{[36]}$ and good inter-professional working and supportive cultures are some of the features which ensure role effectiveness. ${ }^{[37]}$

In summary, how nurses contend with the stress of their professional role has been of interest for decades, and research indicates that clinical nurses' stress derives from both organizational and professional factors. ${ }^{[38]}$ Stress as an interest of study has mainly focused on the individual experiences of nurses, and seldom in the context of the primary health care. This is especially the case when investigating the phenomenon either amongst or within teams.

Hence, the aim of this study was to describe the experienced stress existing among nursing teams working in primary health care. The research questions addressed in this study were: What differences exist in the levels of experienced stress between nurses' teams working in primary health care? What are the correlations between the sub-categories of stress at a team level?

Published by Sciedu Press

\section{METHOD}

\subsection{Design, sampling and data collection}

A descriptive research design was used in this study. ${ }^{[39]}$ All of the public funded primary health care centres $(n=18)$ in one of 10 counties of Lithuania were asked to participate in this study, which was conducted from August 2009 to January 2010. The inclusion criterion for the purposive sample was being a nurse member of a multidisciplinary team caring for clients in the public health sector. In total, 187 nurses ( $\mathrm{n}=579$ ) from 29 teams working in 18 primary health care centres were investigated. For data collection, team meetings $(n=29)$ were organized by the researcher. Nurses who participated in the team meetings completed the questionnaire, which took no more than 20 minutes to complete, and returned them in sealed envelopes to the researcher who was present at the meeting.

\subsection{Instrument}

The questionnaire consisted of background factors and the Expanded Nursing Stress Scale (ENSS) with 59 items, ${ }^{[40]}$ which was developed from the Nursing Stress Scale. ${ }^{[11]}$ The background questions considered the respondent's age, education, and their length of work experience in health care, primary health care, and in their present organization. Also recorded were the patient groups that the respondent worked with and their specialist area.

The ENSS consists of nine subscales: death and dying (7 items), conflict with physicians (4 items), inadequate preparation ( 3 items), problems with peers (6 items), problems with supervisors (7 items), workload (8 items), uncertainty concerning treatment ( 9 items), patients and their families (8 items) and discrimination (3 items). Nurses were asked to respond to the question "how stressful has it been for you" using a response scale of: $0=$ does not apply, $1=$ never stressful $-4=$ extremely stressful. The validity and reliability of the instrument used has been demonstrated in previous studies. Cronbach's alpha value of the ENSS was measured at 0.96 by the original authors, ${ }^{[40]}$ and in other studies it has been measured as $0.82,{ }^{[42]} 0.74-0.88,{ }^{[43]}$ and $0.94{ }^{[44]}$ In this study, the internal consistency coefficient of each subscale (Cronbach's alpha) ranged from 0.64 to 0.87 ("conflict with physicians", "inadequate preparation", and "problems with peers" - 0.64 to 0.77 ; other subscales -0.85 to 0.87 )

For this study, the instrument was translated into the Lithuanian language, then back translated into English by two certified translators. The face validity of the instrument was checked by an expert panel, ${ }^{[39]}$ and the ENSS was also pilot tested with 23 nurses to confirm its content validity. 


\subsection{Participants}

The county-wide population of nurses working in public funded primary health care centres $(n=18)$ was 579 , and 187 nurses from 29 multi-professional teams participated in this study. The number of nurses who responded in each team varied from 2-13 (mean =6.41). Most of the nurses had extensive experience in nursing. $77 \%$ of the nurses had more than 20 years' work experience in health care, and about half (48\%) had worked in primary health care for more than 20 years. About the same number of nurses $(46 \%)$ had more than 20 years experience in their present organization. The majority $(81 \%)$ of the nurses who participated in the study were $>40$ years of age.

The mean age (49.2) among the nurses' teams was quite high (range 43.9 years -63.3 years), and the time nurses had worked in health care $($ mean $=27.8)$ was quite long (range 21.7 years -42.0 years). The length of work experience in primary health care $($ mean $=20.9)$ varied among the teams (range 10.6 years -34.5 years), as did their length of work experience in their present organization $($ mean $=20.2$, range 5.6 years -35.0 years).

The educational background for $85 \%$ of the nurses consisted of two-year programmes of studies provided in medical schools. The teams covered in the study worked with all patient age groups and covered all specialized areas of primary health care (such as family health care, child health care and elderly care).

\subsection{Data analysis}

Analyses of the relationship between the nine subscales of nurses' stress (ENSS) and team membership were conducted using MANOVA. ${ }^{[45,46]}$ Partial eta squared values were calculated in order to assess the magnitude of impact of the membership of the team on nurses' stress.

Correlation analysis was used to identify the relationship between variables, and the Pearson product-moment correlation coefficient was calculated. A $t$-test was used to establish whether the correlation coefficient was significantly different from zero. The cluster analysis method was used to group teams by the nature of their experienced stress. Cluster analysis is an data analysis tool which aims at sorting different objects into groups, so that the degree of association between two objects is maximal if they belong to the same group, and minimal if otherwise. ${ }^{[47]}$ Hierarchical cluster analyses using the Ward's minimum-variance method and squared Euclidean distance as the similarity measure were used. The differences between clusters were evaluated using ANOVA.

\subsection{Ethical issues}

An ethical statement for the study was obtained from the ethical committee of the Health Sciences Faculty of Klaipeda State University of Applied Sciences. The directors of the primary health care centres also gave their individual permission for the study to be performed. The researcher organized team meetings for the data collection and provided participants with both oral and written information about the purpose of the study, confirming their rights to confidentiality and anonymity. The study conformed to the auspices of the Declaration of Helsinki. ${ }^{[48]}$

\section{Results}

3.1 Differences in the levels of experienced stress between nurses' teams working in primary health care

Measurements of stress are usually studied at the individual level. However, this more detailed analysis shows that stress can also be studied as a team level variable. There was a statistically significant difference in nurses stress (overall), based on the team membership (the application of MANOVA revealed: $F=1.30, p=.004$, Wilk's $\Lambda=0.16$, partial $\left.\eta^{2}=0.20\right)$. This means that working in a particular team can either increase or decrease the level of stress (determines different level of stress), and the partial $\eta^{2}$ shows that working in different teams can have the effect of averaging stress levels.

When analyzing whether different stress sub-categories vary between different nurses' teams, no significant differences were identified (the results are presented in Table 1, and all $p$-values are $>.05)$. This can be explained by the fact that the sample was not large $(\mathrm{n}=187)$, and additionally, the nurses' teams were small (the average nurses team size was 6.41). When the sample size is small, important effects can be seen as non-significant. However, the partial $\eta^{2}$ ranged from 0.13 to 0.19 for most sub-categories of stress, and shows that the team may have an effect averaging stress levels. Working in some teams may have effect of discrimination emanating from stress (partial $\eta^{2}=0.33$ ) (few teams pointed out high levels of stress in the discrimination area).

The results (see Table 1) show that the difference between the maximum and minimum stress values (assigning the average stress within the team) is large. Partial eta squared values close to 0.15 indicate a medium-sized influence of the team membership on stress. Furthermore, the stress level was also analyzed as a team characteristic, by using the team as a unit of analysis. The average $z$-transformation of the stress measurement scales were calculated for each team.

The background factors among the teams were not significantly associated with the sub-categories of stress. There 
was a weak statistically significant correlation between team relationship between the average age of the nurses' team and size and "workload" ( $p=.028$ ) (see Table 2), with "work- "inadequate preparation" was found.

load" causing more stress in larger teams. Also a negative

Table 1. Univariate effect of team membership

\begin{tabular}{|c|c|c|c|c|c|}
\hline \multirow{2}{*}{ Dependent Variable } & \multicolumn{2}{|c|}{ Team Mean (z-scale) } & \multicolumn{3}{|c|}{ Anova } \\
\hline & Min & Max & $F$ & Sig. & Partial Eta Squared \\
\hline Death and dying & -0.80 & 1.27 & 0.9 & .57 & 0.15 \\
\hline Conflict with physicians & -0.77 & 0.84 & 1.0 & .43 & 0.16 \\
\hline Inadequate preparation & -1.21 & 0.87 & 1.3 & .15 & 0.19 \\
\hline Problems with peers & -0.81 & 0.95 & 1.3 & .17 & 0.19 \\
\hline Problems with supervisors & -1.01 & 1.09 & 1.1 & .33 & 0.17 \\
\hline Workload & -0.96 & 0.63 & 0.90 & .62 & 0.13 \\
\hline Uncertainty concerning treatment & -1.10 & 1.12 & 1.1 & .29 & 0.17 \\
\hline Patients and their families & -1.43 & 0.73 & 1.1 & .38 & 0.16 \\
\hline Discrimination & -0.77 & 1.57 & 1.1 & .36 & 0.33 \\
\hline
\end{tabular}

Table 2. Nurses' team level background factors correlation with the sub-categories of stress $\left(\mathrm{n}_{\text {nurses teams }}=29^{* *}\right)$

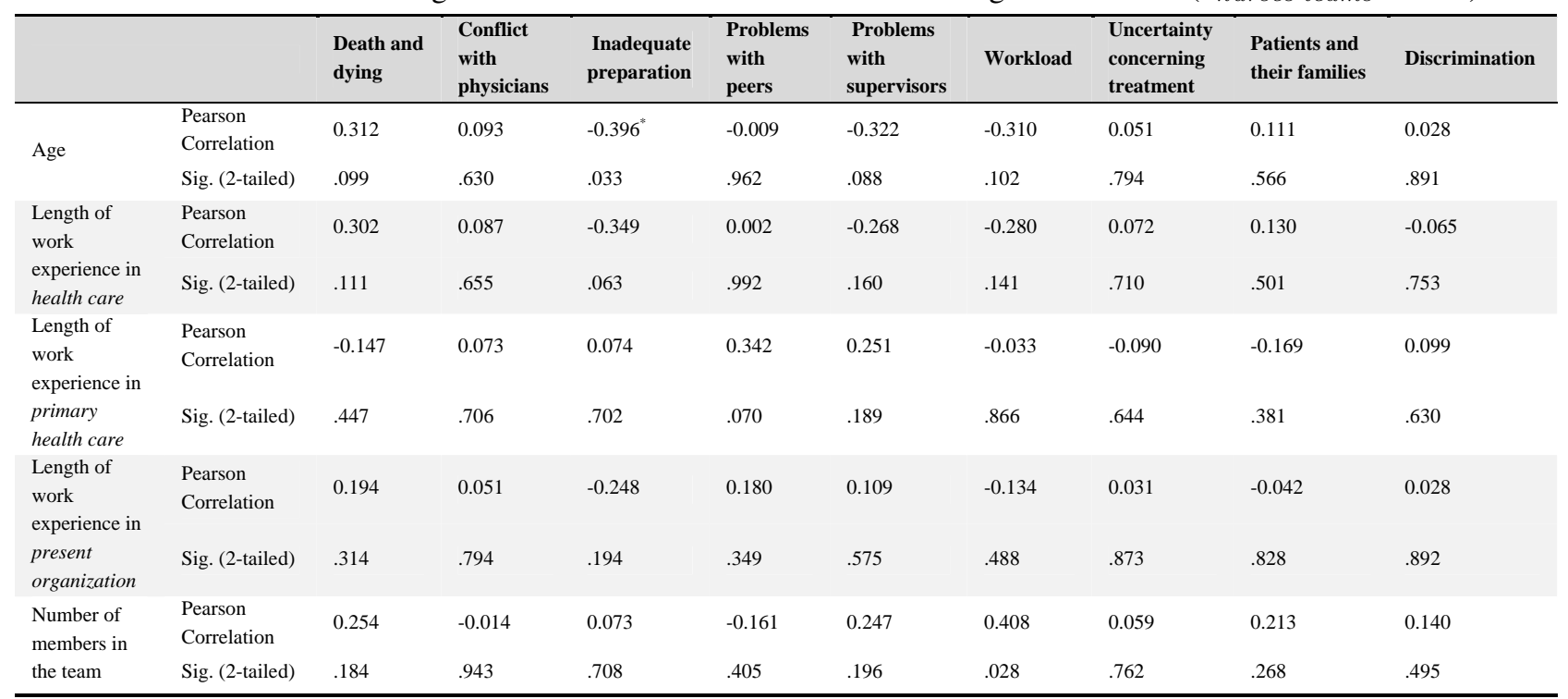

Note. ${ }^{*}$ Correlation is significant at the 0.05 level (2-tailed); ${ }^{* *} \mathrm{n}=26$ only in sub-category of Discrimination

\subsection{Correlations between the sub-categories of team stress}

Correlations between nine sub-categories of stress were evaluated. At the nurses' team level, there seemed to be a strong positive correlation (significant at the .01 level, 2-tailed) between all of the stress subcategory areas investigated, except for that of "discrimination". "Death and dying" was seen to cause more stress in teams where a larger number of nurses experienced stress regarding "uncertainty concerning treatments", as well as "patients and their families" and "conflict with physicians". When teams experienced stress connected with "conflict with physicians", it seemed to have correlations with their experiences with "uncertainty concerning

Published by Sciedu Press treatments" and "inadequate preparation".

Where there was an experience of stress connected to "conflict with physicians", "problems with peers", "problems with supervisors", all of these dimensions induced stress in nurse's relations with others team members (i.e. if the nurse's team had disagreements, then this was seen to be reflected in all of the other dimensions) and correlated with each other. Also, the nurses' teams experienced stress when "problems with peers" and "problems with supervisors" connected to experienced stress in situations with "workload", "uncertainty concerning treatment" and "patients and their families".

The teams experienced stress concerning "inadequate prepa- 
ration" which correlated with stress when having "problems with peers", "problems with supervisors", and "workload" and "uncertainty concerning treatments". Teams also experienced stress connected to "uncertainty concerning treatment", which in-turn caused more stress relating to dealing with "patients and their families" (see Table 3).

In order to group the nurses' teams according to their stress levels, cluster analyses were conducted. These revealed different stress profiles for different teams, based on their common features in various clusters. The four cluster model was chosen (see Figure 1). The difference between the clusters assessing each component of stress was seen as statistically significant $(F[27,193]=1.30, p<.001$, Wilk's $\Lambda=0.07$, partial $\left.\eta^{2}=0.59\right)$.

Table 3. Correlations between the sub-categories of stress $\left(\mathrm{n}_{\text {nurses teams }}=29^{* * *}\right)$

\begin{tabular}{|c|c|c|c|c|c|c|c|c|c|c|}
\hline & & $\begin{array}{l}\text { Death } \\
\text { and } \\
\text { dying }\end{array}$ & $\begin{array}{l}\text { Conflict with } \\
\text { physicians }\end{array}$ & $\begin{array}{l}\text { Inadequate } \\
\text { preparation }\end{array}$ & $\begin{array}{l}\text { Problems } \\
\text { with peers }\end{array}$ & $\begin{array}{l}\text { Problems } \\
\text { with } \\
\text { supervisors }\end{array}$ & Workload & $\begin{array}{l}\text { Uncertainty } \\
\text { concerning } \\
\text { treatment }\end{array}$ & $\begin{array}{l}\text { Patients } \\
\text { and their } \\
\text { families }\end{array}$ & Discrimination \\
\hline $\begin{array}{l}\text { Death and } \\
\text { dying }\end{array}$ & $\begin{array}{l}\text { Pearson } \\
\text { Correlation } \\
\text { Sig. (2-tailed) }\end{array}$ & 1 & & & & & & & & \\
\hline $\begin{array}{l}\text { Conflict with } \\
\text { physicians }\end{array}$ & $\begin{array}{l}\text { Pearson } \\
\text { Correlation } \\
\text { Sig. (2-tailed) }\end{array}$ & $\begin{array}{l}0.492^{* *} \\
.007\end{array}$ & 1 & & & & & & & \\
\hline $\begin{array}{l}\text { Inadequate } \\
\text { preparation }\end{array}$ & $\begin{array}{l}\text { Pearson } \\
\text { Correlation } \\
\text { Sig. (2-tailed) }\end{array}$ & $\begin{array}{l}0.298 \\
.116\end{array}$ & $\begin{array}{l}0.517^{* *} \\
.004\end{array}$ & 1 & & & & & & \\
\hline $\begin{array}{l}\text { Problems with } \\
\text { peers }\end{array}$ & $\begin{array}{l}\text { Pearson } \\
\text { Correlation } \\
\text { Sig. (2-tailed) }\end{array}$ & $\begin{array}{l}0.330 \\
.081\end{array}$ & $\begin{array}{l}0.574^{* *} \\
.001\end{array}$ & $\begin{array}{l}0.518^{* *} \\
.004\end{array}$ & 1 & & & & & \\
\hline $\begin{array}{l}\text { Problems with } \\
\text { supervisors }\end{array}$ & $\begin{array}{l}\text { Pearson } \\
\text { Correlation } \\
\text { Sig. (2-tailed) }\end{array}$ & $\begin{array}{l}0.305 \\
.107\end{array}$ & $\begin{array}{l}0.586^{* *} \\
.001\end{array}$ & $\begin{array}{l}0.654^{* *} \\
<.001\end{array}$ & $\begin{array}{l}0.590^{* *} \\
.001\end{array}$ & 1 & & & & \\
\hline Workload & $\begin{array}{l}\text { Pearson } \\
\text { Correlation } \\
\text { Sig. (2-tailed) }\end{array}$ & $\begin{array}{l}0.233 \\
.223\end{array}$ & $\begin{array}{l}0.378^{*} \\
.043\end{array}$ & $\begin{array}{l}0.532^{* *} \\
.003\end{array}$ & $\begin{array}{l}0.599^{* *} \\
.001\end{array}$ & $\begin{array}{l}0.561^{* *} \\
.002\end{array}$ & 1 & & & \\
\hline $\begin{array}{l}\text { Uncertainty } \\
\text { concerning } \\
\text { treatment }\end{array}$ & $\begin{array}{l}\text { Pearson } \\
\text { Correlation } \\
\text { Sig. (2-tailed) }\end{array}$ & $\begin{array}{l}0.713^{* *} \\
<.001\end{array}$ & $\begin{array}{l}0.634^{* *} \\
<.001\end{array}$ & $\begin{array}{l}0.531^{* *} \\
.003\end{array}$ & $\begin{array}{l}0.524^{* *} \\
.004\end{array}$ & $\begin{array}{l}0.640^{* *} \\
<.001\end{array}$ & $\begin{array}{l}0.559^{* *} \\
.002\end{array}$ & 1 & & \\
\hline $\begin{array}{l}\text { Patients and } \\
\text { their families }\end{array}$ & $\begin{array}{l}\text { Pearson } \\
\text { Correlation } \\
\text { Sig. (2-tailed) }\end{array}$ & $\begin{array}{l}0.696^{* *} \\
<.001\end{array}$ & $\begin{array}{l}0.521^{* *} \\
.004\end{array}$ & $\begin{array}{l}0.460^{*} \\
.012\end{array}$ & $\begin{array}{l}0.408^{*} \\
.028\end{array}$ & $\begin{array}{l}0.560^{* *} \\
.002\end{array}$ & $\begin{array}{l}0.456^{*} \\
.013\end{array}$ & $\begin{array}{l}0.720^{* *} \\
<.001\end{array}$ & 1 & \\
\hline Discrimination & $\begin{array}{l}\text { Pearson } \\
\text { Correlation } \\
\text { Sig. (2-tailed) }\end{array}$ & $\begin{array}{l}0.325 \\
.106\end{array}$ & 0.184 & $\begin{array}{l}0.296 \\
.142\end{array}$ & $\begin{array}{l}0.120 \\
.559\end{array}$ & $\begin{array}{l}0.011 \\
.958\end{array}$ & $\begin{array}{l}0.097 \\
.637\end{array}$ & $\begin{array}{l}0.238 \\
.241\end{array}$ & $\begin{array}{l}0.240 \\
.238\end{array}$ & 1 \\
\hline
\end{tabular}

Note. ${ }^{*}$ Correlation is significant at the 0.05 level (2-tailed); ${ }^{* *}$ Correlation is significant at the .01 level (2-tailed); ${ }^{* * *} \mathrm{n}=26$ only in sub-category of Discrimination



Figure 1. Examples of the stress profiles of nurses' teams distributed among four clusters

Teams falling in the first cluster $(c l 1, \mathrm{n}=10)$ were characterized by an average stress level. Teams falling in the second cluster $(c / 2, \mathrm{n}=6)$ showed a low level of stress. Teams falling in the third cluster $(c l 3, n=7)$ were characterized by a relatively low level of stress caused by "death and dying", "conflict with physicians", "inadequate preparation", "patients and their families", and average stress relating to "problems with peers", "problems with supervisors" and stress caused by "workload". Teams falling in the fourth cluster ( $c l 4, n=3)$ showed a high level of stress in all of the identified stress dimensions.

Figure 2 illustrates the cluster distribution of teams comparing two dimensions of stress - "inadequate preparation" and "problem with supervisors". The figure depicts different symbols belonging to different clusters teams. The first cluster ( $c l 1)$ denotes teams in which nurses experienced average levels of stress due to "inadequate preparation" and "problems with supervisors". The third cluster ( $c l 3)$ distinguished teams 
in which stress caused by "inadequate preparation" was relatively low, and stress relating to "problems with supervisors" was seen as average.

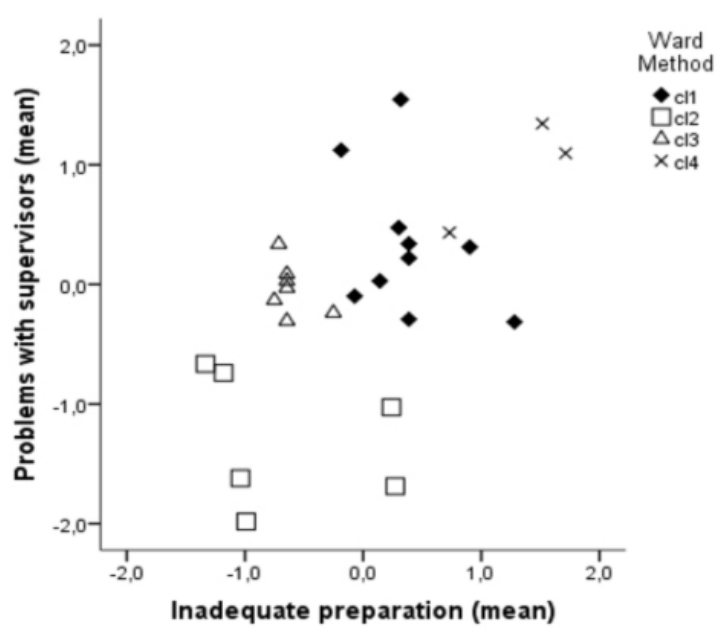

Figure 2. The correlation between areas of "inadequate preparation" and "problems with supervisors"

\section{Discussion}

The strength of this study is that the participants represented all of the primary health care centres operating in one Lithuanian county with a staffing level of $\geq 6$, and altogether, 29 teams participated. These results may therefore be considered as being possibly representative of the situation of bigger health care centres within the country. Although the sampling ratio (sampling fraction) in this study was $32 \%$ of the target population, this could still be considered as a limitation of this study. A further limitation is that the instrument used has been developed to measure stress at the individual level and not at the team level.

The results of this study showed the different variations in nurses' experienced stress that exist between teams working in primary health care. Nurses from larger and smaller primary health care teams participated in the study. Whilst larger teams come from larger health care centres which may offer more collegial support outside of the nurses' team; in smaller centres, teams may possibly feel as if they are left to work more in isolation. Therefore, it is important that smaller teams are given a wider colleague network in which to interact. According to Laschinger, ${ }^{[31]}$ working with supportive colleagues who respect each other's contribution to the patient care process can however go a long way in dealing with the stressors that arise in today's stressful health care environments.

The larger nurses teams showed they experienced more stress concerning their workload. This can be explained by the fact

Published by Sciedu Press that that these teams were from larger health care centres with a commensurately large number of community members. In the large health care centres of Lithuania, workload ratio (client/worker) is bigger compared with smaller centres. Nurse team members with an older age and longer duration of work experience in health care reported increased levels of experienced stress connected to inadequate preparation. This may be somewhat unexpected because we could assume that the longer a person has worked, the more prepared they are to cope with stressful events. However, it may be that older nurses are more sensitive when encountering stressful situations and do not know how to manage them effectively. Different findings concerned with different age groups have also been found, and studies by Kirkcaldy and Martin ${ }^{[11]}$ and Lee and Wang ${ }^{[12]}$ found that younger public health nurses with a shorter duration of work experience also perceive a higher level of occupational stress.

When evaluating the correlations between the sub-categories of teams' stress, a strong positive correlation (significant at the .01 level, 2-tailed) was found between all of the subcategory areas, except for that of "discrimination". In the context of this study, discrimination could be understood by primary health care nurses as a dimension not connected with work relations (e.g. gender, nationality, and race). This seems quite expected while clients of the primary health care nurses are quite heterogenous.

The study results showed that teams which experienced stress connected to "conflict with physicians" have correlations with "uncertainty concerning treatments" and "inadequate preparation". If the team experience stress with the physician, then it also seems to experience stress in other areas such as an "uncertainty concerning treatments" and "inadequate preparation". This presents a challenge for management as to how primary health care centres may be developed to work on a more multi-professional basis. The core issue seems to be develop effective communication between physicians and other health care professionals, however difficulties in interprofessional interaction have been cited as one of the problems which Lithuanian health care currently faces. ${ }^{[25]}$

Where there was an experience of stress connected to "conflict with physicians", "problems with peers", or "problems with supervisors", all of these dimensions induced stress in the nurses' relations with others. Thus Rushmore ${ }^{[27]}$ reported that nurses are willing to collaborate in teamwork. This is also important for Lithuanian primary health care nurses, because they continue to work in a traditional hierarchical relationship with family physicians. ${ }^{[23]}$ Likewise Mellor ${ }^{[34]}$ says that team meetings and training for managers on identifying and managing stress are important, but this does not 
take place in Lithuania primary health care centres in general.

In this study, it was found that teams experienced stress concerning "inadequate preparation" connected with stress when having "problems with peers", "problems with supervisors", and as well as with "workload" and their "uncertainty concerning treatments". According to Pinikahana and Happell, ${ }^{[14]}$ "workload" was the highest perceived stressor followed by "inadequate preparation" for rural psychiatric nurses. Also district nurses reported most stressful aspects work overload and a lack of teamwork with other departments. ${ }^{[15]}$

This study found different stress profiles. According to similarities in stress experiences, the teams represent different cluster types. The variation between these stress profiles shows the differences between the experienced stresses found among teams. Three of the teams falling in the fourth cluster (cl4) showed a high level of stress in all of the identified stress dimensions, whilst others showed an average or low stress level. This variation should be noticed by managers when developing and supporting improvements in the working lives of nurses.

\section{Conclusions}

In particular, interventions that will help build interpersonal relationships, develop conflict resolution skills, and which develop our understanding of the role that effective teamwork has in lessening work-related stress are required.

There are several implications for nurse managers which should be highlighted based on this study. Managers should be aware of the variation of experienced stress among nurses working in different teams in the primary health care sector. It is critical to create an environment that can engender team effectiveness through team building. In order for managers to help nursing teams, an appropriate and relevant evaluation of what happens in the teams is essential, and this includes coverage of those elements and characteristics that relate to work-related stress in the nursing environment. Our analysis showed that there were a group of teams (a cluster) with a high level of stress in all of the identified stress dimensions, so this urges managers to act immediately. However, there were also teams showing an average or low stress level, and this variation should be noticed by managers when developing and supporting improvements in the working lives of nurses. The situation for the manager with teams with different cluster profiles presents difficult challenges in their everyday management work. For the evaluation of the present situation among teams, a regular system of longitudinal evaluation is central.

\section{Financial support}

This study has been partly funded by Pirkanmaa Hospital District (EVO 9N074), Satakunta Hospital District (EVO 81041), Tampere University, and the Finnish Cultural Foundation.

\section{CONFlicts OF INTEREST Disclosure}

The authors declare that they have no competing interests.

\section{REFERENCES}

[1] Evans AM, Pereira DA, Parker JM. Occupational distress in nursing a psychoanalytic reading of the literature. Nursing Philosophy. 2008; 9: 195-204. PMid: 18582295. http://dx.doi.org/10.1111/j .1466-769X.2008.00356.x

[2] Muscroft J, Hicks C. A comparison of psychiatric nurses' and general nurses' reported stress and counselling needs: a case study approach. Journal of Advanced Nursing. 1998; 27: 1317-1325. PMid: 9663884 http://dx.doi.org/10.1046/j.1365-2648.1998.00656.x

[3] McVicar A. Workplace stress in nursing: a literature review. Journal of Advanced Nursing. 2003; 44: 633-642. PMid: 14651686 http://dx.doi.org/10.1046/j.0309-2402.2003.02853.x

[4] Happell B, Dwyer T, Reid-Searl K, et al. Nurses and stress: recognizing causes and seeking solutions. Journal of Nursing Management 2013; 21: 638-647. PMid: 23700980. http://dx.doi.org/10.11 $11 /$ jonm. 12037

[5] Glazer S, Gyurak A. Sources of occupational stress among nurses in five countries. International Journal of Intercultural Relations. 2008; 32: 49-66. http://dx.doi.org/10.1016/j.ijintrel.2007.1 0.003

[6] Gonge H, Buus N. Model for investigating the benefits of clinical supervision in psychiatric nursing: a survey study. International Jour- nal of Mental Health Nursing. 2011; 20: 102-111. PMid: 21371225. http://dx.doi.org/10.1111/j.1447-0349.2010.00717.x

[7] Lee JKL. Job stress, coping and health perceptions of Hong Kong primary care nurses. International Journal of Nursing Practice. 2003; 9: 86-91. PMid: 12694477. http://dx.doi.org/10.1046/j.1 322-7114.2003.00413.x

[8] Coomber B, Barriball KL. Impact of job satisfaction components on intention to leave and turnover for hospital-based nurses: A review of the research literature. International Journal of Nursing Studies. 2007; 44: 297-314. PMid: 16631760. http://dx.doi.org/10.10 16/j.ijnurstu. 2006.02.004

[9] Hayes SC, Luoma J, Bond F, et al. Acceptance and Commitment Therapy: Model, processes, and outcomes. Behaviour Research and Therapy. 2006; 44(1): 1-25. PMid: 16300724. http://dx.doi.o rg/10.1016/j.brat.2005.06.006

[10] Lu H, Barriball KL, Zhang X, et al. Job satisfaction among hospital nurses revisited: A systematic review. International Journal of Nursing Studies. 2012; 49: 1017-1038. PMid: 22189097. http://dx.doi.org/10.1016/j.ijnurstu.2011.11.009

[11] Kirkcaldy BA, Martin T. Job stress and satisfaction among nurses: individual differences. Stress Medicine. 2000; 16(2): $77-$ 
89. http://dx.doi.org/10.1002/(SICI) 1099-1700(200003 ) $16: 2<77::$ AID-SMI835>3.0.CO;2-Z

[12] Lee I, Wang H. Perceived occupational stress and related factors in public health nurses. The Journal of Nursing Research. 2002; 10(4): 253-259. PMid: 12522738. http://dx.doi.org/10.1097 /01. JNR. 0000347606.91295 .76

[13] Lenthall S, Wakerman J, Opie T, et al. What stresses remote area nurses? Current knowledge and future action. Australian Journal of Rural Health. 2009; 17(4): 208-213. PMid: 19664086. http://dx.doi.org/10.1111/j.1440-1584.2009.01073.x

[14] Pinikahana J, Happell B. Stress, burnout and job satisfaction in rural psychiatric nurses: a Victorian study. Australian Journal of Rural Health. 2004; 12(3): 120-125. PMid: 15200523. http: //dx.doi.org/10.1111/j.1440-1854.2004.00572.x

[15] Shimeles A. Community Based Health Insurance Schemes in Africa: the Case of Rwanda. African Development Bank Group. Working Paper. 2010; 120. PMid: 11979211. http://dx.doi.org/10.12 968/bjon.2002.11.8.10167

[16] Montoro-Rodriguez J, Small JA. The role of conflict resolution styles on nursing staff morale, burnout, and job satisfaction in long-term care. Journal of Aging \& Health. 2006; 18(3): 385-406. PMid: 16648392. http://dx.doi.org/10.1177/0898264306286196

[17] Ericson-Lidman E, Norberg A, Persson B, et al. Healthcare personnel's experiences of situations in municipal elderly care that generate troubled conscience. Scandinavian Journal of Caring Sciences. 2013; 27(2): 215-223. PMid: 22612532. http://dx.doi.org/10.1111 /j.1471-6712.2012.01017.x

[18] Tunnah K. Stress in hospice at home nurses: a qualitative study of their experiences of their work and wellbeing. International Journal of Palliative Nursing. 2012; 18(6): 283-289. PMid: 22885901. http://dx.doi.org/10.12968/ijpn.2012.18.6.283

[19] Tucker M, Jimmieson NL, Oei TP. The relevance of shared experiences: A multi-level study of collective efficacy as a moderator of job control in the stressor-strain relationship. Work \& Stress. 2013; 27(1): 1-21. http://dx.doi.org/10.1080/02678373.2013.772356

[20] Saltman R. Drawing the strands together: primary care in perspective. Pages 68-82. IN: Saltman, R.B., Rico, A. and Boerma, W. (Eds.) Primary care in the driver's seat. Organizational reform in European primary care. Berkshire, England: Open University Press; 2006.

[21] Jurgutis A, Vainiomäki P, Stašys R. Primary health care quality indicators for a more sustainable health care system in Lithuania. Management theory and studies for rural business and infrastructure development. 2011; 26(2): 76-86.

[22] Supreme Council of Lithuania: Lithuanian National Conception of Health, Vilnius. Decree NoI-1939. 1991 (accessed 23 January 2016, in Lithuanian). Available from: https://www.e-tar.1t/portal /1t/legalAct/TAR.66813A09EB5B

[23] Jaruseviciene L, Liseckiene I, Valius L, et al. Teamwork in primary care: perspectives of general practitioners and community nurses in Lithuania. BMC Family Practice. 2013; 14: 118. PMid: 23945286. http://dx.doi.org/10.1186/1471-2296-14-118

[24] Jaruseviciene L, Valius L, Baubiniene A, et al. Sexual and reproductive health care of an adolescent at the primary health care level: the role of the family physician. Lithuanian Family Physician (Lietuvos bendrosios praktikos gydytojas). 2006; 10: 182-186.

[25] Bankauskiene V, Jakusovaite I. Dealing with ethical problems in the healthcare system in Lithuania: achievements and challenges. Journal of Medical Ethics. 2006; 32(10): 584-587. PMid: 17012499. http://dx.doi.org/10.1136/jme.2005.014761

[26] Cioffi J, Wilkes L, Cummings J, et al. Multidisciplinary teams caring for clients with chronic conditions: experiences of community nurses and allied health professionals. Contemporary Nurse. 2010;
36(1-2): 61-70. PMid: 21254823. http://dx.doi.org/10.5172 /conu. 2010.36.1-2.061

[27] Rushmore R. Blurred boundaries damage inter-professional working. Nurse Researcher. 2005; 12: 74-85. http://dx.doi.org/10.77 $48 / \mathrm{nr} 2005.01 \cdot 12 \cdot 3 \cdot 74 . \mathrm{c} 5950$

[28] Hagglund D. District continence nurses' experiences of their continence service in primary health care. Journal of Nursing Management. 2010; 18(2): 225-233. PMid: 20465750. http://dx.doi .org/10. $1111 / \mathrm{j} .1365-2834.2009 .01021 . \mathrm{x}$

[29] Ekedahl M, Wengström Y. Coping processes in a multidisciplinary healthcare team-a comparison of nurses in cancer care and hospital chaplains. European Journal of Cancer Care. 2008; 17(1): 42-48. PMid: 18181890. http://dx.doi.org/10.1111/j.1365-2354. $2007.00801 . x$

[30] Dackert I. The impact of team climate for innovation on well-being and stress in elderly care. Journal of Nursing Management. 2010; 18: 302-310. PMid: 20546470. http://dx.doi.org/10.1111/j $.1365-2834.2010 .01079 . \mathrm{x}$

[31] Laschinger HK. Positive working relationships matter for better nurse and patient outcomes. Journal of Nursing Management. 2010; 18(8): 875-877. PMid: 21073561. http://dx.doi.org/10.1111/j.1 365-2834.2010.01206.x

[32] Kuusio H, Heponiemi T, Vänskä J, et al. Psychosocial stress factors and intention to leave job: differences between foreign-born and Finnish-born general practitioners. Scandinavian Journal of Public Health. 2013; 41(4): 405-411. PMid: 23508947. http: //dx.doi.org/10.1177/1403494813477248

[33] Kinnunen-Amoroso M. Finnish occupational physicians' and nurses' experience of work related stress management: a qualitative study. Industrial Health. 2011; 49(6): 774-778. PMid: 22020021. http: //dx.doi.org/10.2486/indhealth.MS1295

[34] Mellor N, Mackay C, Packham C, et al. Management standards' and work-related stress in Great Britain: Progress on their implementation. Safety Science. 2011; 49: 1040-1046. http://dx.doi.org /10.1016/j.ssci.2011.01.010

[35] Haycock-Stuart EA, Houston NM. Evaluation study of a resource for developing education, audit and teamwork in primary care. Primary Health Care Research and Development. 2005; 6: 251-268. http://dx.doi.org/10.1191/1463423605pc249oa

[36] Gilin Oore D, Leblanc D, Day A, et al. When respect deteriorates: incivility as a moderator of the stressor-strain relationship among hospital workers. Journal of Nursing Management. 2010; 18(8): 878-888. PMid: 21073562. http://dx.doi.org/10.1111/j.1365-2834. 2010.01139. $\mathrm{x}$

[37] Poulton B, McKenna H, Keeney S, et al. The role of the public health nurse in meeting the primary health care needs of single homeless people: a case study report. Primary Health Care Research and Development. 2006; 7: 135-146. http://dx.doi.org/10.1191/1 463423606pc278oa

[38] Feng RF, Tsai YF. Socialization of new graduate nurses to practising nurses. Journal of Clinical Nurses. 2012; 21(13-14): 2064-2071. PMid: 22384849. http://dx.doi.org/10.1111/j.1365-2702. 2011.03992. $\mathrm{x}$

[39] Polit DF, Beck CHT, Hungler BP. Essentials of nursing research: Methods, appraisal, and utilization. $5^{t h}$ Edition. Philadelphia: Lippincott; 2001.

[40] French SE, Lenton R, Walters V, et al. An empirical evaluation of an Expanded Nursing Stress Scale. Journal of Nursing Measurement. 2000; 8(2): 161-178. PMid: 11227582.

[41] Gray-Toft P, Anderson JG. The Nursing Stress Scale: development of an instrument. Journal of Psychopathology and Behavioral As- 
sessment. 1981; 3: 11-23. http://dx.doi .org/10.1007/BF013 21348

[42] McGilton KS, McGillis Hall L, Wodchis WP, et al. Supervisory support, job stress, and job satisfaction among long-term care nursing staff. JONA. 2007; 37(7/8): 366-372. http://dx. doi .org/10.10 97/01. NNA.0000285115.60689.4b

[43] Por J. A pilot data collecting exercise on stress and nursing students. British Journal of Nursing. 2006; 14(22): 1180-1184. PMid: 16509434. http://dx.doi.org/10.12968/bjon.2005.14.22. 20169

[44] Milutinović D, Golubović B, Brkić N, et al. Professional stress and health among critical care nurses in Serbia. Arh Hig Rada Toksikol. 2012; 12(63): 171-180. http://dx.doi.org/10.2478/10004-1 254-63-2012-2140
[45] Brown B, Hendrix S, Hedges D, et al. Multivariate Analysis for the Biobehavioral and Social Sciences - A Graphical Approach. 2012. http://dx.doi.org/10.1002/9781118131626

[46] Anthony D. Statistics for Health, Life and Social Sciences. BookBoon.com; 2011.

[47] Everitt BS, Landau S, Leese M, et al. Cluster Analysis, $5^{\text {th }}$ Edition. John Wiley \& Sons, Ltd; 2011.

[48] World Medical Association. Declaration of Helsinki - Ethical Principles for Medical Research Involving Human Subjects. $64^{\text {th }}$ WMA General Assembly, Fortaleza, Brazil, October, 2013 (accessed 5 May 2014). Available from: http://www.wma.net/en/30publicati ons/10policies/b3/ 